\title{
Faktor-Faktor Prediktor Perilaku Pembelian Emas di Pekanbaru
}

\author{
AFRED SUCI \\ Fakultas Ekonomi Universitas Lancang Kuning Pekanbaru \\ Jalan Yos Sudarso KM 8 Rumbai \\ Telp.(0761) 52581 email: afred_75@yahoo.com
}

\begin{abstract}
The present research was conducted at Plaza Sukaramai Pekanbaru, a Gold Sales Center in Pekanbaru. The study needs to find out the effect of product attribute, price and culture on the buying behaviors of the Pekanbaru consumers. The sample consisted of 160 buyers who were selected using the combination of cluster and purposive sampling technique. The variables are the product attribute, prices and culture as the independent variables, and the buying behavior as the dependent one. The data were analyzed using multiple regression analysis. The study reveals that product attribute has a positive and significant effect on the buying behavior. The price has a positive and significant effect on the buying behavior. Culture has a positive but insignificant effect on buying behavior.
\end{abstract}

Keywords: Product Attribute, Price, Culture and Buying Behavior

Emas merupakan suatu komoditi langka yang menjadi pilihan investasi penting bagi masyarakat. Sifatnya yang tidak mudah rusak, tahan lama, memiliki nilai yang tetap dan harga perolehan yang terus meningkat, serta terbatas ketersediaannya menjadi keunggulan tersendiri dibandingkan dengan alat investasi atau alat tukar seperti uang kartal (uang kertas dan logam). Selain memiliki nilai investasi jangka panjang, emas juga memiliki nilai estetika unik, dimana dapat diolah menjadi beragam bentuk perhiasan.

Keistimewaan emas sebagai produk investasi dibandingkan produk-produk investasi lain seperti produk investasi keuangan, emas bisa sekaligus dipergunakan sebagai sarana pencitraan diri bagi pemiliknya. Bagi wanita, emas seakan-akan menjadi bagian tak terpisahkan dari proses berhias diri dan juga simbol status sosial. Dan ternyata dewasa ini, fenomena sosial seperti ini tidak hanya terbatas pada wanita, namun juga sudah menggejala pada konsumen pria. Inilah yang kemudian menjadi keistimewaan emas yang menjadikannya sebagai produk investasi yang unik dan memiliki nilai tambah bagi pemiliknya.

Perdagangan emas sendiri memiliki keunikan yang mungkin jarang ditemukan pada produk lainnya. Produk emas bisa dikatakan kebal krisis, maksudnya ketika terjadi penurunan konsumsi/pembelian pada produk-produk lain pada saat terjadi resesi atau krisis, namun perdagangan emas justru tidak mengalami penurunan, dan bahkan pada beberapa tempat, krisis dan resesi justru mampu meningkatkan konsumsi/pembelian produk-produk emas, baik berupa batangan maupun yang sudah berbentuk perhiasan. Dengan alasan ini maka menarik untuk mengkaji perilaku pembelian konsumen terhadap produk emas.

Meskipun secara sederhana berinvestasi emas menjanjikan manfaat ekonomis yang menguntungkan, namun tidak selalu berkorelasi positif bagi konsumen untuk secara konsisten membeli emas. Apalagi hanya menetapkan satu atau dua toko emas sebagai tempat pembelian perhiasan bagi konsumen. Ini cukup sulit mengingat banyaknya persaingan antar toko emas yang ada, sehingga pilihan pada toko bukan menjadi faktor yang sangat utama bagi konsumen untuk memutuskan pembelian (North, et., al., 2008).

Dari beberapa alternatif terbaik yang tersedia, konsumen akan memutuskan untuk membeli atau sebaliknya tidak membeli, sebelum akhirnya melakukan evaluasi pasca pembeliannya untuk menilai apakah ia merasakan kepuasan atau tidak (Simamora, 2013). Tahapan yang dijalankan oleh 
konsumen ini diistilahkan sebagai perilaku konsumen yang berarti, tindakan yang langsung terlibat untuk mendapatkan, mengkonsumsi, dan menghabiskan produk dan jasa, termasuk proses pengambilan keputusan yang mendahului dan mengikuti tindakan ini (Engel, et., al., 2011).

Di Pekanbaru, sentra penjualan emas berada di Plaza Sukaramai. Disana sedikitnya terdapat sekitar 128 toko mas, yang menempati beberapa blok yang memang dikhususkan oleh pengelola gedung, PT Pengelola Sukaramai, menjadi pusat penjualan emas di kota Pekanbaru. Dipilihnya Plaza Sukaramai sebagai sentra penjualan emas di kota Pekanbaru tak terlepas dari banyaknya pedagang toko emas yang memilih tempat tersebut untuk berjualan emas. Masyarakat pun sudah mengetahui bahwa untuk mendapatkan pilihan emas yang bervariasi dan bermutu tinggi, maka Plaza Sukaramai adalah tempatnya. Banyaknya toko mas disana menyebabkan persaingan harga dan kualitas emas yang akan menguntungkan bagi konsumen. Tingginya tingkat persaingan yang ada mengharuskan pengelola toko mas yang ada harus memahami bagaimana perilaku para konsumen yang ingin membeli emas.

Perilaku konsumen sulit untuk diprediksi dengan tepat, karena banyak faktor yang mempengaruhinya. Sehingga perlu kiranya dilakukan studi mendalam untuk mengetahui faktor-faktor yang sekiranya dapat mempengaruhi perilaku konsumen emas, khususnya di kota Pekanbaru. Salah satu pertimbangan bagai konsumen ketika hendak membeli emas adalah faktor atribut produk. Penelitian Ekawati (2012) menunjukkan menekankan pentingnya atribut produk yang direpresentasikan dalam bentuk ukuran produk dan juga dipengaruhi oleh harga. Hasil ini sejalan dengan penelitian Henny (2008) yang menyimpulkan bahwa faktor pengembangan variasi produk berkorelasi kuat dan positif dengan penjualan perhiasan emas. Demikian pula pengembangan tipe produk yang tepat lebih mampu mempertahankan keberlanjutan preferensi (pilihan) konsumen pada satu produk tertentu (Chung, 2011). Toko emas yang mampu melakukan pengembangan variasi dan tipe produk perhiasan mampu memberikan alternatif pilihan kepada konsumennya, sehingga dapat memuaskan keinginan konsumen untuk mencoba sesuatu yang baru dan berbeda dalam setiap pembeliannya.

Di samping atribut produk, faktor lain yang bisa mempengaruhi perilaku konsumen adalah harga. Dari aspek harga ini, perilaku dan keputusan pembelian emas konsumen cukup sulit untuk diprediksi. Misalnya ketika di tahun 2008 dan 2010 ketika terjadi krisis global dimana harga emas sedang meningkat tajam, justru penjualan perhiasan emas di hampir seluruh toko emas di Plaza Sukaramai meningkat hingga $25 \%$ dibandingkan ketika harga emas sedang normal. Padahal dari aspek hukum ekonomi, semestinya semakin tinggi harga akan dapat menurunkan tingkat konsumsi atau pembelian, terlebih perhiasan emas bukan menjadi kebutuhan primer sehingga tidak ada keterpaksaan untuk membeli atau mengkonsumsinya.

Riset yang dilakukan oleh Draganska \& Jain (2008) menyimpulkan bahwa kebijakan harga yang berbeda dapat sebabkan oleh lini produk dimana, kebijakan harga justru yang menjadi faktor yang lebih mempengaruhi preferensi konsumen (Draganska \& Jain, 2008). Pergerakan harga yang tiba-tiba secara drastis, dapat mempengaruhi konsumen untuk menunda pembelian emas (Lutter, 2008). Kedua penelitian ini memperlihatkan bagaimana harga dapat mempengaruhi perilaku dan keputusan pembelian konsumen terhadap produk perhiasan emas.

Demikian pula dengan atribut produk dan harga tidak semata-mata menjadi faktor paling utama bagi konsumen dalam keputusan pembelian perhiasan emas. Bagi konsumen wanita di India, faktor pendorong utama membeli perhiasan emas justru karena pengaruh budaya seperti untuk perayaan keagamaan, perkawinan, hari kelahiran. Sehingga bagi konsumen emas di India, berbelanja perhiasan emas sudah merupakan 
ritual. Di samping itu, wanita India juga kerap menjadikan emas sebagai pilihan investasi. Karena sudah membudaya maka, banyak wanita India yang rajin melihat pergerakan kurs harga emas sebelum berbelanja (Tariq, et., al., 2007). Selain itu, budaya membeli emas di India sangat terkait dengan status yang menjadi faktor sangat kuat dalam keputusan konsumen untuk membeli perhiasan emas (Ratna \& Malhotra, 2006). Ternyata konsumen perhiasan di India memiliki kesamaan dengan karakteristik konsumen perhiasan berlian di Banjarmasin, dimana dimensi gaya hidup yang paling dominan mempengaruhi keputusan pembelian berlian adalah pola kebiasaan-kebiasaan yang dilakukan oleh masyarakat yang hidup di tengah-tengah para pengrajin perhiasan disana (Ilhamiyah, et.,al., 2012).

\section{METODE}

Jenis penelitian dilakukan dengan pendekatan deskriptif kuantitatif untuk menguji aspek korelasional dari faktor-faktor prediktor (independen) terhadap variabel independen. Data-data penelitian bersifat primer dan dikumpulkan dengan mempergunakan kuesioner tertutup. Populasi penelitian adalah pengunjung di Plaza Sukaramai yang pernah melakukan pembelian emas di toko-toko mas yang terdapat di lokasi tersebut. Pembatasan jumlah sampel mengacu kepada saran dari Hair (dalam Ferdinand, 2006), bahwa ukuran sampel minimum yang digunakan dalam penelitian survei dapat dihitung dengan cara: 5 hingga 10 dikali jumlah indikator variabel. Jumlah indikator variabel dalam penelitian ini adalah sebanyak 16 item. Sehingga dengan demikian, ukuran sampelnya menjadi: $10 \times 16=160$ responden . Pemilihan sampel dilakukan secara convenience sampling. Adapun proses pengujian dilakukan secara parametrik dengan mempergunakan alat bantu SPSS 22 for windows.

\section{HASIL}

Perilaku konsumen dalam membeli emas di Pekanbaru sangat dipengaruhi oleh sejumlah faktor prediktor. Berdasarkan hasil penelitian ditemukan bahwa atribut produk, harga dan budaya cukup mempengaruhi perilaku konsumen dalam pembelian emas di Pekanbaru yang ditunjukkan dengan nilai koefisien determinasi sebesar 53,9\%. Secara simultan ketiga faktor prediktor ini mempengaruhi perubahan yang terjadi pada perilaku pembelian emas secara signifikan. Dengan demikian maka bagi pemasar emas di Plaza Sukaramai Pekanbaru perlu untuk meningkatkan atribut produk dari sisi kualitas, desain dan variasi, menjaga daya saing harga pasaran serta memperhatikan budaya pada masyarakat di Pekanbaru agar bisa mengenali perilaku pembeliannya.

Untuk menentukan apakah besaran pengaruh yang terjadi memiliki dampak signifikan atau tidak dapat dilihat pada tabel berikut ini. Jika nilai $t_{\text {statistik }}$ lebih besar $t_{\text {tabel }}$ maka sifat hubungan/pengaruh yang terjadi adalah signifikan. Sedangkan jika nilai $t_{\text {statistik }}$ lebih kecil dari nilai $t_{\text {tabel }}$ maka sifat hubungan/pengaruh yang terjadi adalah tidak signifikan.

Tabel 1

Hasil Pengujian Signifikansi

\begin{tabular}{|l|c|c|c|c|}
\hline & $\begin{array}{c}\text { Nilai } \\
\text { Koefisien } \\
\text { Regresi }\end{array}$ & $\begin{array}{c}\text { Nilai } \\
\mathbf{t}_{\text {statistik }}\end{array}$ & $\begin{array}{c}\text { Nilai } \\
\mathbf{t}_{\text {tabel }}\end{array}$ & $\begin{array}{c}\text { Kriteria } \\
\text { Hubungan } \\
\text { Yang } \\
\text { Terjadi }\end{array}$ \\
\hline $\begin{array}{l}\text { Atribut } \\
\begin{array}{l}\text { Produk } \\
\text { Perilaku } \\
\text { Pembelian }\end{array}\end{array}$ & 0.537 & 5.798 & 1.975 & Signifikan \\
\hline $\begin{array}{l}\text { Harga } \\
\text { Perilaku } \\
\text { Pembelian }\end{array}$ & 0.419 & 5.958 & 1.975 & Signifikan \\
\hline $\begin{array}{l}\text { Budaya } \rightarrow \\
\text { Perilaku } \\
\text { Pembelian }\end{array}$ & 0.147 & 1.410 & 1.975 & Tidak \\
\hline
\end{tabular}

Sumber: Data olahan

\section{PEMBAHASAN}

\section{Pengaruh Atribut Produk Terhadap Perilaku Pembelian}

Hasil penelitian menunjukkan bahwa atribut produk berpengaruh positif dan signifikan terhadap perilaku pembelian perhiasan emas. Semakin tinggi penilaian konsumen terhadap atribut produk perhiasan emas maka perilaku pembeliannya akan semakin aktif. Secara teoritis, hasil penelitian 
ini sejalan dengan kesimpulan penelitian yang dilakukan oleh Mahmudah (2008) bahwa ada korelasi yang erat dan searah antara produk dengan tingkat penjualan perhiasan emas. Beberapa penelitian terdahulu juga menyatakan bahwa emas sebagai wujud produk fisik menjadikan sejumlah atribut di dalamnya sebagai faktor paling utama dalam preferensi dan keputusan pembelian konsumen (Ekawati, 2012; dan Chung, 2011). Maka hasil ini semakin menguatkan argumentasi umum bahwa dalam perilaku pembelian perhiasan emas, aspek-aspek produk yang terkandung dalam perhiasan emas menjadi pertimbangan sangat penting bagi konsumen sebelum membelinya.

Aspek yang dipertimbangkan paling kuat adalah mengenai desain atau model perhiasan emas yang dijual di toko emas. Sedangkan pertimbangan terkait variasi model perhiasan emas yang dijual memiliki penilaian yang sedikit lebih rendah. Hal ini memperlihatkan bahwa dalam membeli perhiasan, konsumen sangat memperhatikan penampilan fisik dari perhiasan yang dijual, karena desain dan model perhiasan diyakini dapat menunjang penampilan pemakainya. Bahkan pada sebagian pemakai perhiasan, bentuk desain tertentu adalah personifikasi pemakainya, atau bisa mewakili karakteristik pemakainya. Misalnya saja, banyak pembeli dari kelompok pria lebih menyukai membeli cincin yang memiliki batu mulia berukuran besar karena bisa menjadi simbol keperkasaan pria. Pembeli dari segmen wanita berkeluarga menyukai motif bunga, sementara segmen remaja lebih menyukai motif binatang atau inisial huruf.

Ada juga konsumen yang menyukai motif-motif yang dekat dengan simbol Islam seperti motif Kabah, bulan bintang, masjid, atau yang bertuliskan "Allah" dan "Muhammad" untuk merepresentasikan karakter pribadi mereka yang dekat dengan agamanya. Tidak jarang pula ada yang menyukai motif polos yang menyimbolkan kesederhanaan karakter dirinya. Banyaknya selera konsumen ini membuat banyak toko emas memberikan pilihan kepada pelanggannya untuk menentukan desain pesanan sendiri, tentu dengan biaya yang sedikit lebih tinggi dibandingka barang yang sudah jadi.

Selera konsumen cenderung berubah mengikuti tren yang terjadi, oleh karenanya perlu bagi toko emas untuk menyediakan sejumlah variasi model atau desain perhiasan bagi konsumen. Hal ini sudah cukup baik dilakukan oleh banyak toko emas di Plaza Sukaramai dengan menyediakan desain beragam dan bahkan kerap berganti-ganti dalam periode tertentu. Seringkali konsumen yang masih menginginkan desain atau model yang lama tidak dapat menemukannya lagi di toko karena model tersebut sudah dianggap diskontinyu (tidak dibuat lagi) oleh toko emas. Untuk mengantisipasi hal ini, konsumen diperbolehkan melakukan pemesanan khusus untuk dibuatkan seperti yang menjadi keinginannya tersebut, tentu dengan biaya yang sedikit lebih mahal.

Maka implikasinya bagi toko mas adalah agar selalu mengikuti perkembangan dan memperkaya jenis desain atau modelmodel terbaru perhiasan emas agar bisa menyesuaikan dengan perkembangan preferensi konsumen. Terlebih cukup banyak konsumen perhiasan emas merupakan kelompok konsumen muda yang belum menikah, yang biasanya mereka cukup sensitif terhadap dinamika perubahan model dan variasi perhiasan emas. Jika konsumen bisa menemukan desain yang diinginkannya maka toko mas berpeluang besar untuk bisa menarik konsumen baru (recruiting) dan mempertahankan pelanggan lama (retaining).

Toko mas juga perlu mempertahankan kebijakan kustomisasi produk berdasarkan pesanan pelanggan, karena tidak semua desain atau model pabrikan bisa memenuhi selera pelanggan. Jika aspek produk sudah dapat memenuhi keinginan pelanggan maka diharapkan pelanggan akan semakin kuat keputusannya untuk membeli perhiasan emas dari satu toko mas tertentu.

\section{Pengaruh Harga Terhadap Perilaku Pembelian}

Hasil penelitian menunjukkan bahwa harga berpengaruh positif dan signifikan 
terhadap perilaku pembelian perhiasan emas. Semakin tinggi harga perhiasan emas maka perilaku pembelian konsumen akan semakin aktif. Harga yang tinggi atau ketidakstabilan harga emas akan menyebabkan konsumen lebih berhati-hati dalam membelanjakan uangnya. Ia akan mencari informasi yang lebih banyak, melakukan tawar menawar dengan lebih ketat dan juga berusaha menemukan satu toko langganan dimana ia merasa nyaman dengan kebijakan harganya. Harga yang semakin tinggi menjadikan konsumen semakin aktif berperilaku yang bisa memberikannya kemudahan untuk mendapatkan harga yang paling rasional bagi dirinya. Pertimbangan harga bisa menjadi alasan seseorang untuk menunda pembelian perhiasan emas.

Secara teoritis hasil penelitian ini cukup sejalan dengan beberapa penelitian terdahulu yang menjadi referensi dalam penelitian ini. Draganska \& Jain (2008) menyimpulkan bahwa faktor harga menjadi pertimbangan utama bagi preferensi pembelian konsumen. Jika terjadi perubahan harga yang drastis maka konsumen akan menunda pembelian emas (Lutter, 2008). Maka hasil ini semakin menguatkan argumentasi umum bahwa dalam pembelian perhiasan emas, aspek-aspek pada harga perhiasan emas menjadi pertimbangan sangat penting bagi konsumen sebelum memutuskan untuk membelinya.

Dengan demikian, implikasinya bagi toko mas adalah agar sering menginformasikan fluktuasi kurs harga emas kepada para pelanggan tetapnya, baik dengan melakukan komunikasi tatap muka maupun dengan mempergunakan media komunikasi. Bagi pelanggan yang sering melakukan pembelian emas, mengetahui fluktuasi kurs emas akan sangat bermanfaat dalam menentukan waktu terbaik untuk melakukan pembelian atau sebaliknya untuk menjualnya kembali. Terlebih dari hasil penelitian memperlihatkan bahwa cukup banyak konsumen yang membeli perhiasan emas lebih dari 1 kali transaksi dalam 3 bulan. Toko mas perlu memiliki statistik perkembangan kurs yang ditampilkan di toko agar konsumen yang sensitif pada harga atau yang memiliki motif ekonomi ketika membeli emas, bisa mempelajari waktu terbaik melakukan transaksi jual beli.

Banyak toko mas di Plaza Sukaramai yang menetapkan kebijakan satu harga pada ongkos pembuatan yang tentu saja kebijakan ini dirasakan memberatkan bagi konsumen yang hanya membeli dalam kadar gram yang ringan. Maka toko mas perlu memberlakukan kebijakan ongkos pembuatan yang progresif, dimana penerapan ongkos diringankan pada pembelian emas dengan kadar ringan, dan terus meningkatkan ongkos untuk setiap penambahan satu gram perhiasan emas.

Sama seperti pada pertimbangan terhadap atribut produk, ternyata masalah harga menjadi pertimbangan yang sangat penting pula bagi rata-rata responden sebelum membeli perhiasan emas. Aspek potongan harga beli menjadi indikator harga yang paling dipertimbangkan, sedangkan kestabilan harga emas menjadi yang paling rendah meskipun bisa dikatakan tidak berbeda jauh dengan skor indikator harga jual kembali.

Masyarakat pada umumnya memang tergolong sensitif terhadap harga, terutama jika jumlah harga yang harus dibayarkan termasuk dalam kategori keterlibatan yang tinggi, dimana emas memerlukan sejumlah pertimbangan yang matang, termasuk masalah harga perolehannya. Semakin besar potongan harga yang bisa didapatkan, tentu akan memberikan nilai tambah yang lebih baik bagi konsumen. Pada toko emas, potongan harga yang paling sering dilakukan atau paling sering menjadi ajang negosiasi adalah pada penerapan ongkos dan bukan pada harga emasnya itu sendiri. Disinilah kemampuan tawar menawar konsumen diuji agar bisa membujuk pedagang untuk menurunkan biaya atau ongkosnya.

Harga emas pun relatif stabil, kecuali bila terjadi hal-hal diluar perkiraan seperti krisis ekonomi seperti di tahun 2008 lalu yang membuat harga emas melambung sangat tinggi. Kestabilan harga emas sangat dibutuhkan dan menjadi pertimbangan penting bagi konsumen mengingat peran 
emas tidak hanya untuk perhiasan namun juga sebagai alat investasi. Jika harganya stabil maka konsumen akan merasa aman bahwa nilai investasinya berada pada tingkatan yang aman. Jikapun terjadi fluktuasi maka diharapkan adalah fluktuasi yang positif atau negatif yang dapat ditoleransi. Dengan kestabilan harga yang baik maka konsumen juga merasa aman bahwa investasi emasnya akan dapat dijual kembali dengan harga yang tinggi sehingga tidak terlalu merugikan secara finansial.

\section{Pengaruh Budaya Terhadap Perilaku Pembelian}

Sama seperti yang terjadi pada konsumen di India sebagaimana yang dirangkum dalam hasil penelitian Tariq, et.,al., (2007), konsumen perhiasan emas di Indonesia, seringkali menjadikan alasan budaya sebagai dasar pertimbangan untuk membeli emas pada momen-momen yang istimewa. Ritual adat perkawinan misalnya, fenomena paling umum yang sering terjadi adalah membeli cincin pernikahan ataupun mahar berupa perhiasan emas. Fakta ini seolah menjadi kebiasaan masyarakat yang ingin melangsungkan pernikahan dan bahkan menjadi bagian tak terpisahkan dari prosesi ritual pernikahan itu sendiri.

Pada budaya masyarakat kontemporer, acara-acara ulang tahun dan prosesi serah terima jabatan (sertijab) di instansi-instansi tertentu sering menjadikan emas sebagai souvenir yang memiliki nilai tertentu. Nilainilai yang lahir dari pemberian souvenir berupa emas diyakini bisa menunjukkan derajat sosial si pemberi maupun si penerimanya. Hal ini menunjukkan bahwa emas memang menjadi simbol-simbol sosial yang sangat kuat pada masyarakat sehingga terkadang menjadikan seseorang menjadi konsumen yang emosional daripada rasional. Maka tak heran, meskipun kurs harga emas sering berfluktuasi tidak stabil, namun intensitas pembelian emas pada masyarakat tetap tinggi.

Namun demikian, pada hasil penelitian ini justru menunjukkan bahwa budaya berpengaruh positif namun tidak signifikan terhadap perilaku pembelian perhiasan emas. Meskipun faktor dorongan budaya pada konsumen semakin tinggi, namun peningkatan keaktifan perilaku pembeliannya tidak berdampak besar.

Hasil penelitian ini secara teoritis cukup bertentangan dengan temuan pada penelitianpenelitian sebelumnya. Membeli emas adalah budaya masyarakat, dan bahkan telah menjadi ritual (Tariq, et., al., 2007) sehingga pertimbangan pada kebiasaan (Ilhamiyah, et., al., 2012) dan status (Ratna \& Malhotra, 2006) seringkali mengalahkan pertimbangan akan produk dan harga dalam hal pembelian perhiasan emas.

Dengan demikian maka temuan penelitian menunjukkan bahwa indikasi perilaku pembelian emas pada masyarakat lebih bersifat pragmatis. Pertimbangan pada faktor yang lebih realistis seperti atribut produk dan fluktuasi harga pasaran emas lebih menentukan perilaku pembelian konsumen. Sehingga dengan demikian sentimen budaya tidak secara signifikan mempengaruhi perilaku pembelian konsumen pada perhiasan emas di Pekanbaru.

Tidak signifikannya pengaruh budaya terhadap perilaku pembelian emas dikarenakan dari hasil temuan deskriptif diketahui bahwa rata-rata responden menanggapi secara biasa saja terhadap aspek budaya yang melatarbelakangi pembelian perhiasan emas. Satu-satunya indikator budaya yang diikuti atau menjadi pertimbangan penting bagi responden dalam membeli perhiasan emas adalah karena faktor kebiasaan untuk berinvestasi dalam bentuk emas. Sedangkan faktor keyakinan agama menjadi indikator yang paling tidak menjadi pertimbangan bagi responden dalam membeli emas. Hal ini dapat dimaklumi mengingat mayoritas responden yang beragama Islam tidak menjalani suatu keharusan untuk mengenakan emas dalam ritual-ritual keagamaan. Jadi mengenakan emas pada ritual keagamaan seperti hari raya hanya merupakan kebiasaan masyarakat dan bukan menjadi anjuran.

Hari-hari istimewa seperti ulang tahun atau pernikahan tidak selalu menjadi alasan 
kuat bagi responden untuk membeli emas. Namun khusus untuk pernikahan memang ada kebiasaan responden untuk membeli perhiasan emas, terutama cincin kawin atau ada juga yang menjadikan perhiasan emas sebagai mahar nikah. Namun untuk hari istimewa secara keseluruhan, rata-rata responden hanya menanggapinya secara biasa saja atau dalam arti kata bukan menjadi pertimbangan penting untuk membeli emas.

Rata-rata responden juga beranggapan bahwa budaya ikut-ikutan bukan merupakan alasan membeli emas, sehingga responden kurang mengikuti kebiasaan masyarakat yang suka membeli emas. Hal ini bisa dimaklumi mengingat tidak semua orang memiliki daya beli yang sama, jadi meskipun keinginan untuk ikut dalam budaya membeli emas, namun jika daya beli tidak mendukung maka hal tersebut tidak dapat dilakukan.

Budaya membeli emas karena ingin menaikkan status sosial responden di masyarakat juga kurang diikuti oleh rata-rata responden. Pada dasarnya membeli emas menunjukkan bahwa kebutuhan primer dan sekunder sudah dapat dipenuhi sehingga masih memiliki anggaran khusus untuk membeli perhiasan emas yang memiliki harga yang relatif tinggi. Meskipun tidak secara terbuka diakui, namun sesungguhnya memang memakai perhiasan emas sedikit banyaknya menimbulkan suatu sensasi psikologis yang menyenangkan dan membanggakan bagi pemakainya, tentu dengan tingkat kebanggaan yang berbeda-beda. Hal ini bisa terjadi karena emas menjadi simbol kemewahan, dan bagi sebagian masyarakat yang berdaya beli tinggi membeli dan mengenakan banyak perhiasan emas merupakan gaya hidup yang melekat dalam kesehariannya.

\section{SIMPULAN}

Perilaku konsumen Pekanbaru dalam membeli emas secara umum sangat ditentukan oleh penilaiannya pada atribut produk dan harga. Semakin baik atribut produk perhiasan emas yang dijual maka perilaku pembelian konsumen akan semakin aktif. Demikian juga semakin tinggi harga perhiasan emas maka perilakunya akan semakin aktif. Namun demikian tidak seperti fenomena kebanyakan pada masyarakat di Asia, ternyata di Pekanbaru budaya tidak menjadi faktor penentu perilaku pembelian emas di masyarakat. Dengan demikian maka masyarakat Pekanbaru dapat dikatakan merupakan tipe pembeli pragmatis yang mengutamakan pada pertimbangan rasional pada produk dan harga.

\section{DAFTAR RUJUKAN}

Chung, Hua, 2011. Sustainable Consumer: The Moderating Effect of Product Type on Sustainability Preference. Master Thesis Maastricht University

Draganska, Michaela dan D.C. Jain, 2008. Consumer Preferences and Product Line Pricing Strategies: An Empirical Analysis. Dipresentasikan pada Marketing Science Conference, 2008, Maryland, USA

Ekawati, N.W., 2012. Analisis Perilaku Konsumen Mancanegara Dalam Keputusan Pembelian Produk Emas dan Perak Pada Toko Kerajinan (Art Shop) di Desa Celuk Gianyar Bali. Tesis Universitas Brawijaya, Malang. http://ppsub.ub.ac.id/perpustakaan/ind ex.php

Engel, James F., David T. Kollat \& Roger D Blackwell, 2011. Perilaku Konsumen. Binarupa Aksara, Jakarta

Ferdinand, Augusty, 2006. SEM Dalam Penelitian Manajemen. BP Undip, Semarang

Henny, Mahmudah, 2008. Peranan Pengembangan Produk Variasi Model Dalam Meningkatkan Volume Penjualan (Pada Toko Emas Proyogi Lamongan). Indonesian Scientific Journal Database, Vol. 2, No. 1, hal. 40-49.

http://isjd.pdii.lipi.go.id/index.php 
Ilhamiyah, Agus. S., dan Margono. S., 2012. Ratna, Vadra, dan G. Malhotra, 2006. Pengaruh Gaya Hidup Konsumen Customer Perception Towards Terhadap Keputusan Pembelian Branded Jewelry in India. Riset dosen Perhiasan Berlian di Kota yang tidak dipublikasikan dari Banjarmasin. Tesis Program Pasca Institute of Management Technology, Sarjana Universitas Brawijaya, Malang. India, dan telah dipresentasikan pada http://ppsub.ub.ac.id/perpustakaan/ind ex.php

Lutter, Jaana Lisette, 2008. Consumer Behaviour During Investment Gold Purcahse in Comparison to Other Investment Instrument. Baltic Film and Media School, Tallinn University 5th SIMSR Asia Marketing Conference, Mumbai-India, tanggal 1-4 Januari 2010. http://www.imt.edu/research/conferen cepresentation.aspx

Simamora, Bilson, 2013. Membongkar Kotak Hitam Konsumen. Gramedia Pustaka Utama, Jakarta

North, E.J., Retha B de Vos, dan T. Kotze, 2003. The Importance of Apparel Product Attributes for Female Buyers. Journal of Family Ecology and Consumer Sciences, Vol. 31, 2003, p. 41-51

Tariq, H., D.S. McKechnie, J. Grant, J. Phillips, 2007. Shopping For Gold! A Ritual Experience. Hasil riset tidak dipublikasikan dari American University of Sharjah, United Arab Emirates, dan telah dipresentasikan pada Academic Business World International Conference, Teneessee, Amerika Serikat, Mei 2007. http://www.ABWIC.org 